\section{"That's my job" Exploring the effect of brand empowerment towards employee brand equity: The mediating role of employee critical psychological states}

\author{
Mohsin Altaf \\ ${ }^{1}$ School of Business Management, Universiti \\ Utara Malaysia, Sintok, Malaysia \\ Arfan Shahzad ${ }^{2}$ \\ ${ }^{2}$ Othman Yeop Abdullah Graduate School of Business, \\ Universiti Utara Malaysia, Sintok, Malaysia
}

\begin{abstract}
Purpose - Based on the recent call to uncover the dynamics of employee psychological states in branding, i.e. employee brand understanding and brand psychological ownership, this study aims to investigate the relationship between brand empowerment, employee psychological states, and their outcome i.e. employee brand equity. Moreover, the study tried to investigate the mediating role of employee psychological states, i.e. employee brand understanding and brand psychological ownership, in the relationship between brand empowerment and employee brand equity.
\end{abstract}

Design/methodology/approach - The survey method was adopted to collect the data from the respondents from public sector banks. Data were collected from 374 employees working in the banking sector using the proportionate stratified random sampling technique.

Findings -The results of this study confirm the positive relationship between brand empowerment, employee psychological states, i.e. employee brand understanding and brand psychological ownership, and employee brand equity. Furthermore, employees' psychological states play a mediating role in the relationship between brand empowerment and employee brand equity, as illustrated in job characteristics theory. Past studies in branding literature have revolved around employees' psychological states and their impact on personal outcomes, i.e. employee brand equity.

Originality/value - Based on the recent call to explore the dynamics of employee psychological states, this study tries to dig deeper into the theory by investigating the link between brand empowerment and employee brand equity.

Keywords - employee brand equity, brand psychological ownership, employee brand understanding, brand empowerment, public banks.
Received on

$11 / 22 / 2017$

Approved on

06/08/2018

\section{Responsible editor:}

Prof. Dr. João Maurício Gama

Boaventura

\section{Evaluation process:}

Double Blind Review 


\section{Introduction}

In 2015, China and Pakistan signed a US $\$ 46$ billion trade route agreement called the China-Pakistan Economic Corridor (CPEC), which is an important part of the "One Belt, One Road" projects that connect Pakistan and the western parts of China to the Arabian Sea (Houreld, 2015). It was reported that the CPEC will generate approximately US $\$ 70$ billion in revenue per year from Chinese cargo transportation (Aamir, 2016). This will create a new set of challenges and opportunities for Pakistani banks. Most Pakistani banks are willing to start operations in China but they will face fierce competition from Chinese ones, which are among the most powerful in the world, with nine Chinese banks ranking among the top twenty-five in the world (Gara, 2016). To overcome these challenges, some significant changes are required to meet the changing dynamics of the new competitive environment. Several top Pakistani banks claim that they are prepared to exploit new business challenges by reorienting their internal banking systems for this purpose (Aazim, 2016). As a strategic posture, banks are urged to adopt a strong brand orientation (Schmitt, 2012). Brand orientation could help in the development of a successful brand through re-orientating the entire organization around brand identity and core brand values (Hankinson, 2012). Consequently, the development of powerful brands and brand equity has become an important top management issue in this current competitive environment (Hirvonen, Laukkanen, \& Reijonen, 2013).

The banking industry provides a large array of services to attract customers and to meet their demands and this, in turn, creates support for the economy (Drigă \& Dura, 2014). As with other services, banks face unique challenges in branding due to the intangible offerings and lack of product and service differentiation between competing banking brands (Bravo, Montaner, $\&$ Pina, 2010). It should be noted that even though private and public sector banks operate in the same environment, the performance of private banks is well above that of public sector banks (State Bank of Pakistan [SBP], 2016), and private banks have shown higher profitability (Waleed, Shah, \& Mughal, 2015). Public banks have shown the worst performance, and they have to endure a highly bureaucratic culture instead of a brandoriented culture, as highlighted by the former governor of the State Bank of Pakistan:

In the government banks the staff worked like typical government employees, coming to office at 9:00 a.m., checking files; having nothing important to do and leaving at 5.00 p.m. without doing much work. These banks suffered from a high bureaucratic approach, unprofitable branches and poor customer service (Husain, 2005, p. 1).

Hence, public sector banks need a brandoriented culture to compete with local and international banks. To this end, employee behavior should represent and communicate the brand values of public sector banks. This is because employees interact closely with clients and are responsible for service delivery and issues related to service delivery (Chelladurai, 2006).

Employees' role in branding has been largely overlooked in branding literature (King, Grace, \& Funk, 2012)2012, as such literature has previously focused on the company's image in the minds of customers. In recent years, companies and academics have started to understand the powerful implication of employees' perceptions of an organization. Most well known marketing scholars believe that customer contentment and loyalty towards a brand spark from the contentment and loyalty among its employees (Boone \& Kurtz, 2012; DiJulius, 2011; HennigThurau \& Hansen, 2013). Thus, in services, the behaviors of employees is the primary determinant of value creation (Ind, 2007), and so 
scholars of this area tend to focus on investigating brand management from inside an organization specifically through the employees. This approach is termed as internal branding. The shift from external branding to internal branding started in the last decade. Employee behavior is required to represent and communicate the brand values of public sector banks. This is because employees interact closely with clients and are responsible for service delivery and issues related to service delivery (Chelladurai, 2006).

Aligning employee behavior with the brand promise is often the focus of internal branding. Considerable efforts have been seen in the branding literature to maintain employee behavior according to the communicated brand value. The literature on internal branding has often focused around the brand related attitudes of employees, i.e. brand commitment and its impact on employees' brand behavior (Burmann, Jost-Benz, \& Riley, 2009; Burmann \& Zeplin, 2005; Burmann, Zeplin, \& Riley, 2009). On the other hand, there are limited research efforts on employees' critical psychological states or their mental processes, i.e. employee brand understanding (Piehler, King, Burmann, \& Xiong, 2016; Xiong, King, \& Piehler, 2013) and brand psychological ownership (Chang, Chiang, \& Han, 2012; Chiang, 2009; Chiang, Chang, Han, \& McConville, 2013), which could be used to manage employees' brand behavior. Moreover, there is little discussion on the antecedents of employee critical psychological states in the branding literature (Altaf, Mokhtar, \& Ghani, 2017; Piehler et al., 2016)2016b. Hence, based on the need to uncover the dynamics of employee critical psychological states (Altaf et al., 2017; Piehler et al., 2016; Xiong et al., 2013), this study examines the effect of brand empowerment on the development of employee critical psychological states, i.e. brand psychological ownership and employee brand understanding, and its effects on employee brand equity.

\section{Literature Review}

\section{I Employee brand equity}

Employee brand equity is the third perspective of brand equity. Previously, the literature on brand equity only focused on the consumer and financial sides (Houreld, 2015; King \& Grace, 2009). In the first decade of this new century, King \& Grace (2009) shifted the paradigm by presenting a new model of employeebased brand equity. This model focused on the employee side of brand equity. King \& Grace (2009) defined employee-based brand equity (King \& Grace) as "The differential effect that brand knowledge has on an employee's response to their work environment" (p. 130). The purpose of employee brand equity is to translate brand identity in a way that is important and meaningful for employees in terms of their roles and responsibilities. In the model, the behavior of the employee was denoted as employee-based brand equity benefits, which were measured through brand citizenship behavior, brand endorsement, brand loyalty, and employee satisfaction. Later, King et al. (2012) modified the measurement of employee-based brand equity benefits and termed them as "employee brand equity". More specifically, they stated that "employee brand equity is the result when an employee possesses brand knowledge that engenders positive, productive employee brand-related behavior that is congruent with the communicated brand identity" (King et al. 2012, p. 271).

\subsection{Employee brand understanding}

Employee brand understanding is defined as an increase in employees' perceptions regarding their roles and responsibilities in brand success as well as their skill in delivering brand promise (Xiong et al., 2013)2013. In other words, employee brand understanding is the "cognitive representation of the brand in the mind of employees" (Piehler et al., 2016). In the same vein, Thomson, Chernatony, Arganbright, and Khan 
(1999) claimed that a good understanding of organizational strategy better prepares employees to identify how their roles can add value to the brand. Organizations may vary in terms of their size and branding practices, but employee brand understanding and employee roles in the delivery of services are fundamental to the service experience (Xiong et al., 2013)2013. Up until now, few attempts have been made to establish employee understanding and employee capability with respect to their role as brand ambassadors. Miles and Mangold (2004) conceptualized the employee branding process and highlighted that it is a process based on the information an employee receives from internal and external sources and from interpreting the information. In addition, King and Grace (2008) revealed that employees need to perceive that the brand values they learn are meaningful, relevant, and important to them in order to achieve extra-role behavior. Otherwise, employees remain neutral and only work according to their job descriptions.

According to Hackman and Oldham (1975), an employee develops different levels of psychological states when he or she is exposed to different job designs that lead the employee towards personal and job outcomes. Different levels of psychological states are job knowledge, job meaningfulness, and job responsibilities, whereas different levels of job designs include skill varieties and task identities. When employees perceive that they are skillful and have sufficient knowledge regarding their work, they are more likely to deliver high quality services (Oldham \& Hackman, 2010). Therefore, according to JCT, as well as previous literature, how employees internalize the brand relates to three factors that constitute employee brand understanding. These factors are: (1) employee perceived brand knowledge, (2) employee perceived brand importance, and (3) employee perceived brand role relevance. Regarding these critical psychological states of employees, Xiong et al. (2013) conceptualized employee brand understanding according to the critical psychological states under JCT. The following section will briefly describe the conceptualization of employee brand understanding under JCT.

\subsection{Brand psychological ownership}

According to Pierce, Kostova, and Dirks (2003), psychological ownership is "the state in which individuals feel as though the target of ownership or a piece of that target is theirs" (i.e., "it is MINE!"). The condition of ownership is based on individual feelings of possessiveness and psychological attachment to an entity (Pierce et al., 2003). According to Parker, Wall, and Jackson (1997), ownership is the feeling of responsibility. More specifically, the level of ownership exists when there is a feeling of high concern with the objectives of the job. In reality, psychological ownership is significantly different from legitimate possession (Chang et al., 2012). Psychological ownership is an individual psychological experience occurring through a mental process, but actual possession is ensured by society (Chang et al., 2012). Without actual possession, employees can still develop psychological ownership through psychological experiences (Rousseau \& Shperling, 2003) that lead them towards the behaviors of citizenship, personal sacrifice, the assumption of risk, experienced responsibility, and stewardship (Pierce et al., 2003).

Chang et al. (2012) defined brand psychological ownership as an "employee psychological experience that produces positive brand attitudes and cognition, such as a feeling of possession towards a corporate brand that leads to a selfless spirit towards brand-related activities" (p. 630). Furthermore, Chang et al. (2012) contended that employees having brand psychological ownership might produce positive attitudes towards a corporate brand, with the employees as a whole defending the corporate brand.

Both brand psychological ownership and organizational psychological ownership may produce an association between an organization and the members of that organization (Chiang, 
2009). Both psychological ownerships are different from each other. In the case of organizational psychological ownership, an employee considers himself as the owner of the organization (Pierce, Kostova, \& Dirks, 2001) and produces a psychological contract that further strengthens the relationship between individual and organization that makes the employee willing to perform extrarole behavior (Rousseau, 1989).

\subsection{Brand empowerment}

Brand empowerment is an important yet less discussed variable in the branding literature. Brand empowerment refers to the freedom and power of employees to act autonomously to provide first-class services to customers in order to protect brand image. The word empowerment is relatively new and represents the notion of granting decision-making authority to employees to enhance performance (Menon, 2001). In other words, empowerment is where authorities give power and discretion for employees to make job-related decisions (Bowen \& Lawler, 2006). This affects the initiation and determination of employee task-oriented behavior (Conger \& Kanungo, 1988). In terms of services, employees who are responsible for delivering services can respond efficiently and effectively to customers' needs and wants (Lee, Nam, Park, \& Ah Lee, 2006; Lytle, Hom, \& Mokwa, 1998). In addition, Bateson (1995) claimed that empowerment makes employees more customer focused, responsible, and responsive towards the customer, which further improves employee self-image and organizational image. Hence, it is more important for organizations to empower employees because employees who interact with customers need the flexibility to make a decision at the point of interaction to keep their customers happy (Hartline \& Ferrell, 1996).

Employees not only need to understand their roles in delivering the brand-related promises but they also need empowerment to support this (King \& Grace, 2010)2010. Brandoriented support is the extent to which employees perceive that the environment of the organization contributes to their brand-related understanding and empowers them towards engaging in brandrelated discretionary behaviors (Burmann $\&$ König, 2011).

The job characteristic of autonomy is the expression of every person's aspiration to build a sense of mastery in their work and be trusted to make decisions (Beyerlein, 2006). Autonomy is the degree to which organizations provide substantial freedom, independence, and discretion to employees in their work (Chelladurai, 2006), which creates a sense of responsibility in the minds of the employees. Most employees undoubtedly work under broad organizational constraints, therefore they want a certain degree of freedom. In management literature, job characteristics theory is broadly used to explain the influence of empowerment on employees' attitudes and behavior. From the job characteristics theory perspective, organizational practices associated with structural empowerment, such as delegating powers and authority to employees, reinforce core job characteristics that further affect employees' critical psychological states (Quinn \& Spreitzer, 1997), which is employee brand understanding. Likewise, in branding, brand-related autonomy or brand empowerment has been discussed in limited studies. According to job characteristics theory, brand empowerment is the brand-related autonomy given to employees where they can make decisions independently.

The job characteristics theory by Hackman and Oldham (1975) and Hackman and Oldham (1976) states that work-related autonomy affects employee psychological states. In fact, both employee brand understanding and psychological ownership are employee psychological states where employees develop an understanding regarding brands in order to perform well. Brand psychological ownership is the state when employees develop a sense of ownership towards the brand by considering themselves responsible for delivering the brand promise, developing brand value effectiveness and aligning themselves 
according to the brand image (Chang et al., 2012). On the other hand, employee brand understanding is the state when they have a cognitive representation of the brand in their minds by developing brand knowledge, brand confidence, brand relevance, and behavioral relevance (Piehler et al., 2016).

Empowered employees feel better about their jobs and become more enthusiastic about serving the customer (Peccei \& Rosenthal, 2001). Moreover, empowered employees are more confident in their ability to contribute towards brand success (Conger \& Kanungo, 1988; Peccei \& Rosenthal, 2001), which further leads the employees towards exhibiting behaviors that are consistent with the brand (Hartline \& Ferrell, 1996). In terms of psychological ownership, Pierce et al. (2003) considered control and empowerment as a major antecedent that raises the level of ownership. Furthermore, Peng \& Pierce (2015) confirmed and suggested that empowerment and control is the factor that enhances employee feelings of ownership and satisfies the effectiveness motive that underpins this psychological state. Hence, we can hypothesize that:

H1: Brand empowerment has a significant positive relationship with employee brand understanding.

H2: Brand empowerment has a significant positive relationship with brand psychological ownership.

As derived from job characteristics theory, employees must not only have the perception that the brand is important for their organizational success, but they should also perceive that they contribute to the brand perception (Hackman $\&$ Oldham, 1976). This is because when employees feel that they have sufficient knowledge about the work, they are personally responsible, and the work is meaningful, they will be more likely to deliver high quality work (Oldham \& Hackman, 2010). Furthermore, Xiong et al. (2013) conceptualized employee brand understanding as the employees' perception about brand knowledge, brand importance, and brand role relevance. Similar to the brand role theory, role ambiguity occurs due to a lack of understanding, which further hurts employee consistency (Kahn, Wolfe, Quinn, Snoek, \& Rosenthal, 1964). Moreover, previous studies have confirmed the positive relationship between employee brand understanding and employees' brand-related behavior in the service sector (Mokhtar, Altaf, \& Ghani, 2018; Piehler et al., 2016; Xiong et al., 2013). Hence, we can hypothesize that employee brand understanding has a positive relationship with employee brand equity. Therefore, the hypothesis is:

\section{H3: Employee brand understanding has a significant positive relationship with employee brand equity.}

Employees who experience psychological ownership facilitate a positive attitude towards an organization or brand (Van Dyne \& Pierce, 2004). This further helps the employees to determine selfexistence and self-meaning (Pierce et al., 2001). Employees' self-existence and self-meaning trigger them to feel that they are effective for the brand and brand-related activities (Chang et al., 2012; Pierce et al., 2001; Van Dyne \& Pierce, 2004). Hence, employee brand psychological ownership may produce an altruistic spirit in employee brand-related behavior (Chang et al., 2012; Podsakoff, MacKenzie, Paine, \& Bachrach, 2000). Empirically, studies of the services sector have also provided a significant link between brand psychological ownership and employee brandrelated behavior (Chang et al., 2012; Chang, Chiang, \& Han, 2015; Chiang, 2009). Hence, we can hypothesize that:

$$
\begin{aligned}
& \text { H4: Brand psychological ownership has } \\
& \text { a significant positive relationship with } \\
& \text { employee brand equity. }
\end{aligned}
$$

Both employee brand understanding and brand psychological ownership are the 
psychological states of employees as mentioned in job characteristics theory (Hackman \& Oldham, 1975, 1976). Autonomy and brand empowerment are core job characteristics, while employee brand equity is the personal outcome of employees. According to job characteristics theory, core job characteristics (brand empowerment) affect employees' psychological states (employee brand understanding and brand psychological ownership), which further affect employees' personal outcomes (employee brand equity). Moreover, job characteristics theory shows that the psychological states (employee brand understanding and brand psychological ownership) mediate the relationship between core job characteristics (brand empowerment) and personal outcomes (employee brand equity). Therefore, we can hypothesize that:

\section{H5: Employee brand understanding mediates the relationship between brand empowerment and employee brand equity.}

H6: Brand psychological ownership mediates the relationship between brand empowerment and employee brand equity.

According to the job characteristics theory by Hackman \& Oldham (1976), employee psychological states mediate the relationship between core job characteristics and employee brand equity. This study considers employees' two psychological states i.e. employee brand understanding and brand psychological ownership, which occur throughout the process of brand empowerment and employee brand equity. Thus, this study tries to dig deeper into the theory in branding by investigating brand empowerment as an antecedent of employees' critical psychological states (employee brand understanding and brand psychological ownership) and examine employees' critical psychological states as a mediator in the relationship.

Based on the hypotheses, the hypothesized model suggests that brand empowerment has a relationship with employee brand understanding and brand psychological ownership, which is further linked with employee brand equity. Moreover, employee brand understanding and brand psychological ownership mediate the relationship between brand empowerment and employee brand equity.

\section{Methodology}

\section{I I n s t r u m e n t a tion and operationalization}

Employee brand equity is a positive endogenous variable in the study and representative of productive employees' brand behavior (King $\&$ Grace, 2010). To measure the construct of employee brand equity, an multi-dimensional scale with eleven items was adopted from the study by King et al. (2012). The construct includes three dimensions: brand consistent behavior, brand allegiance, and brand endorsement. All of these dimensions are reflective in nature. Moreover, employee brand understanding is the mediating variable in the study, which is the employees' cognitive representation of the brand (Piehler et al., 2016). A thirteen-item multi-dimensional construct was adopted from the study by Piehler et al. (2016). The construct was measured through four dimensions, including brand confidence, brand knowledge, brand relevance, and behavioral relevance. All of these dimensions are reflective in nature.

Brand psychological ownership is the second mediating variable in the study. The construct contains three dimensions (brand value effectiveness, the employees' responsibility for maintaining brand image, and concurrence between brand image and individual) and could be measured through nine items. All of these dimensions are also reflective. This scale was adopted from the study by Chang et al. (2012). Finally, the one-dimensional five-item scale to measure the construct of brand empowerment was adopted from the studies by Morhart, Herzog, and Tomczak (2009) and King, So, and Grace (2013). 
The construct was gauged by a total of 38 items and included in the study to measure the four constructs. These constructs exclude demographic information comprising information on gender, age, management level, and education. All of the items were measured on a six-point Likert-type scale ranging from $1=$ Strongly Disagree to $6=$ Strongly Agree.

Table 1

\section{Construct profiling}

\begin{tabular}{|c|c|c|c|}
\hline Construct & Defined & Dimensions & Source \\
\hline Employee Brand Equity & $\begin{array}{l}\text { The outcome of brand knowledge } \\
\text { that produces brand-related } \\
\text { behavior that is aligned with the } \\
\text { brand identity communicated }\end{array}$ & $\begin{array}{l}\text { Brand consistent behavior } \\
\text { Brand allegiance } \\
\text { Brand endorsement }\end{array}$ & King et al. (2012) \\
\hline $\begin{array}{l}\text { Employee Brand } \\
\text { Understanding }\end{array}$ & $\begin{array}{l}\text { Cognitive representation of the } \\
\text { brand in the mind of employees }\end{array}$ & $\begin{array}{l}\text { Brand confidence } \\
\text { Brand knowledge } \\
\text { Brand relevance } \\
\text { Behavioral relevance }\end{array}$ & Piehler et al. (2016) \\
\hline $\begin{array}{l}\text { Brand Psychological } \\
\text { Ownership }\end{array}$ & $\begin{array}{l}\text { Employees have freedom and } \\
\text { power to act autonomously in } \\
\text { order to provide first-rate service } \\
\text { as well as contributing towards a } \\
\text { positive brand image }\end{array}$ & $\begin{array}{l}\text { Brand value effectiveness } \\
\text { The employees' responsibility for } \\
\text { maintaining brand image } \\
\text { Concurrence between brand image and } \\
\text { individual }\end{array}$ & Chang et al. (2012) \\
\hline Brand Empowerment & $\begin{array}{l}\text { Employee psychological experience } \\
\text { that produces positive brand } \\
\text { attitude and cognition such as a } \\
\text { feeling of possession towards a } \\
\text { corporate brand }\end{array}$ & Uni-dimensional & $\begin{array}{l}\text { Morhart et al. (2009) and } \\
\text { King et al. (2013) }\end{array}$ \\
\hline
\end{tabular}

\subsection{Sampling procedure and data collection}

The population of this study is the employees of public sector banks of Pakistan. There is a total of 27,248 employees working in 2101 branches of five public sector banks in the country. Based on Krejcie and Morgan (1970), a 379 sample size is regarded as sufficient to represent the population, but due to sample attrition, 600 questionnaires were distributed. Similar to Ahmad (2010), we distributed six questionnaires to each branch and 100 branches were selected from 2101 branches based on proportionate stratified random sampling (See Appendix A). During the second stage, respondents working in the branches were selected via simple random sampling using a random number table as proposed by Rand Corporation (Rand Corporation, 2001). The survey was self-administered and involved the use of enumerators. The data were collected from the period between October 2016 and February 2017 from all the capital cities of four provinces in Pakistan. However, only 396 questionnaires were returned, and only 374 were considered for analysis after problematic questionnaires were removed. Therefore, the response rate of the study was $62.66 \%$.

\subsection{Sample characteristics}

Table 2 presents the information about sample characteristics. The data were collected from 232 male respondents (62.03\%) and 142 female respondents (37.97\%). 25.13\% (94) of the respondents belong to the 21-24 age group and $20.05 \%$ (75) of the respondents belong to the $25-28$ age group; $32.09 \%$ (120) are from the 29-32 age group; $13.10 \%$ (49) are from the 3335 age group; and $9.63 \%$ (36) of the respondents are over 35 years old. Moreover, 45.19\% (169) of the respondents are at the start of their careers, while $37.97 \%$ (142) are middle-level managers, 
and $16.84 \%$ (63) hold high level management positions. In terms of educational level, $12.03 \%$ (45) of the respondents had the first level of education, i.e. matriculation, while $16.84 \%$ (63) of the respondents had intermediate certificates; $29.14 \%$ (109) of the respondents graduated with a bachelor's degree and 41.71\% (156) had a master's degree. Only one respondent had a PhD degree.

Table 2

\section{Sample Profiling}

\begin{tabular}{lccc}
\hline Variable & & Frequency & Percentage \\
\hline Gender & Male & 232 & $62.03 \%$ \\
& Female & 142 & $37.97 \%$ \\
& Total & 374 & $100 \%$ \\
\hline Age & $21-24$ & 94 & $25.13 \%$ \\
& $25-28$ & 75 & $20.05 \%$ \\
& $29-32$ & 120 & $32.09 \%$ \\
& $33-35$ & 49 & $13.10 \%$ \\
& $>35$ & 36 & $9.63 \%$ \\
Level of Management & Total & 374 & $100 \%$ \\
\hline Education & Initial Career & 169 & $45.19 \%$ \\
& Middle Level Manager & 142 & $37.97 \%$ \\
& High Level Management & 63 & $16.84 \%$ \\
& Total & 374 & $100 \%$ \\
\hline & Matriculation & 45 & $12.03 \%$ \\
& Intermediate & 63 & $16.84 \%$ \\
& Bachelor & 109 & $29.14 \%$ \\
& Master & 156 & $41.71 \%$ \\
& PhD & 1 & $0.27 \%$ \\
& Total & 374 & $100 \%$ \\
\hline
\end{tabular}

\section{Results of the Study}

\section{I Preliminary analysis}

A few preliminary tests were conducted before the inferential analysis. Multivariate nonnormality was tested using Mardia's test, where multivariate kurtosis also indicated multivariate non-normality. Hence, in the situation of non-parametric data analysis, the partial least squares structure equation modeling technique is recommended. Moreover, Levene's test for equality of variance for early and late respondents was carried out and found no difference between early and late respondents. In addition, common method bias (CMB) was tested using Herman's one-factor test (Harman, 1967), where the total variance for one factor was $34.68 \%$. Hence, common method bias is not an issue in this study.

\subsection{Measurement of outer model}

The data were analyzed using SmartPLS version 3.2, introduced by Ringle, Wende, and Becker (2015). PLS-SEM was used for this study because the data is non-normal. Moreover, the study is based on second-order constructs. PLSSEM can deal with such constructs easily.

The data were analyzed in two steps. The outer model was measured in the first step, where we checked the reliabilities and validities of the constructs using outer loadings, composite reliabilities (CR), average variance extracted (AVE), and Cronbach's alpha values. The direct and indirect relationships were measured in the 
second stage, where the structural model was analyzed.

Table 3 describes the outer model values, including the outer loading, AVE, CR, and alpha values. All of the loading values ranged from 0.662 to 0.902 . The recommended threshold level for standardized loading is 0.70 , as mentioned by Hair, Hult, Ringle, and Sarstedt (2016). Adhering to the standard, all of the items exceeded the threshold level of 0.50 , as all CR values ranged from 0.817 to 0.916 , hence none of the items were removed. All of the CR values met the threshold level of 0.70 .

In addition, the discriminant validity was assessed by using the Hetrotrait-Monotrait (HTMT) ratio. Table 4 shows the HTMT ratio values. All the values are lower than 0.90, which ensures discriminant validity.

Table 3

First order and second order detail, item labeling, loadings, average variance extracted, composite reliability, and Cronbach's alpha

\begin{tabular}{|c|c|c|c|c|c|}
\hline First Order & Second Order & \multicolumn{2}{|c|}{ Loadings } & AVE & CR \\
\hline BEm & Uni-Dimensional & \multicolumn{2}{|c|}{$0.654-0.767$} & 0.492 & 0.828 \\
\hline $\mathrm{CON}$ & & \multicolumn{2}{|c|}{$0.811-0.813$} & 0.659 & 0.853 \\
\hline RES & & \multicolumn{2}{|c|}{$0.759-0.836$} & 0.648 & 0.847 \\
\hline \multirow[t]{4}{*}{ EFF } & & \multicolumn{2}{|c|}{$0.750-0.806$} & 0.603 & 0.820 \\
\hline & $\mathrm{BPO}$ & $\mathrm{CON}$ & 0.879 & 0.783 & 0.916 \\
\hline & & RES & 0.902 & & \\
\hline & & EFF & 0.874 & & \\
\hline BA & & \multicolumn{2}{|c|}{$0.662-0.775$} & 0.546 & 0.827 \\
\hline $\mathrm{BCB}$ & & \multicolumn{2}{|c|}{$0.751-0.794$} & 0.599 & 0.817 \\
\hline \multirow[t]{4}{*}{ EN } & & \multicolumn{2}{|c|}{$0.774-0.810$} & 0.633 & 0.873 \\
\hline & $\mathrm{EBE}$ & BA & 0.868 & 0.757 & 0.903 \\
\hline & & $\mathrm{BCB}$ & 0.852 & & \\
\hline & & EN & 0.889 & & \\
\hline $\mathrm{BC}$ & & $0.796-$ & & 0.651 & 0.849 \\
\hline BK & & $0.800-$ & & 0.679 & 0.864 \\
\hline $\mathrm{BR}$ & & $0.761-$ & & 0.646 & 0.846 \\
\hline \multirow[t]{5}{*}{$\mathrm{BeR}$} & & $0.790-$ & & 0.638 & 0.841 \\
\hline & EBU & $\mathrm{BC}$ & 0.829 & 0.721 & 0.912 \\
\hline & & $\mathrm{BK}$ & 0.862 & & \\
\hline & & $\mathrm{BR}$ & 0.824 & & \\
\hline & & $\mathrm{BeR}$ & 0.880 & & \\
\hline
\end{tabular}


Table 4

HTMT Matrix

\begin{tabular}{|c|c|c|c|c|c|c|c|c|c|c|}
\hline & BeR & BA & BC & BCB & Bem & EN & BK & BR & EF & $\mathrm{CON}$ \\
\hline $\mathrm{BA}$ & 0.740 & & & & & & & & & \\
\hline $\mathrm{BC}$ & 0.625 & 0.827 & & & & & & & & \\
\hline BCB & 0.710 & 0.629 & 0.781 & & & & & & & \\
\hline BEm & 0.754 & 0.685 & 0.755 & 0.688 & & & & & & \\
\hline $\mathrm{EN}$ & 0.783 & 0.812 & 0.771 & 0.863 & 0.682 & & & & & \\
\hline BK & 0.676 & 0.664 & 0.826 & 0.783 & 0.702 & 0.796 & & & & \\
\hline $\mathrm{BR}$ & 0.722 & 0.633 & 0.785 & 0.844 & 0.493 & 0.738 & 0.861 & & & \\
\hline EFF & 0.729 & 0.677 & 0.810 & 0.789 & 0.802 & 0.673 & 0.792 & 0.703 & & \\
\hline $\mathrm{CON}$ & 0.799 & 0.765 & 0.833 & 0.830 & 0.773 & 0.784 & 0.862 & 0.812 & 0.798 & \\
\hline RES & 0.829 & 0.792 & 0.767 & 0.838 & 0.750 & 0.720 & 0.854 & 0.713 & 0.725 & 0.830 \\
\hline
\end{tabular}

Note $. \mathrm{BC}=$ Brand Confidence, $\mathrm{BR}=$ Brand Relevance, $\mathrm{BeR}=$ Behavioral Relevance, $\mathrm{BK}=\mathrm{Brand}$ Knowledge, $\mathrm{EBE}=$ Employee Brand Equity, $\mathrm{BCB}=$ Brand Consistent Behavior, $\mathrm{BA}=$ Brand Allegiance, $\mathrm{BE}=\mathrm{Brand}$ Endorsement, $\mathrm{EFF}=\mathrm{Brand}$ Value Effectiveness, RES = Responsibility for maintaining brand image, $\mathrm{CON}=$ Concurrence between Brand Image and Individual, $\mathrm{BPO}=$ Brand psychological ownership, $\mathrm{BEm}=$ Brand Empowerment, $\mathrm{BC}=\mathrm{Brand}$ Confidence, $\mathrm{BK}=\mathrm{Brand}$ Knowledge, $\mathrm{BR}=$ Brand Relevance, $\mathrm{BeR}=$ Behavioral Relevance, $\mathrm{EBU}=$ Employee Brand Understanding

\subsection{Measurement of structural model}

Concerning the structural relationships, brand empowerment positively influences brand psychological ownership $(\beta=0.654$, t-value $\left.=18.549, \mathrm{f}^{2}=0.749\right)$, and the effect size is substantial. Moreover, brand empowerment positively influences employee brand equity $\left(\beta=0.635, \mathrm{t}\right.$-value $\left.=16.580, \mathrm{f}^{2}=0.676\right)$, and the effect size is substantial. In addition, employee brand understanding positively influences employee brand equity $(\beta=0.238$, $\mathrm{t}$-value $\left.=2.941, \mathrm{f}^{2}=0.048\right)$. This effect size is relatively small. Finally, brand psychological ownership also positively influences employee brand equity $\left(\beta=0.582\right.$, $t$-value $\left.=7.426, f^{2}=0.287\right)$, and the effect size is substantial. All of these values confirm all the hypotheses in this study.

Table 5

Path analysis, effect size $\left(f^{2}\right)$, predictive relevance $\left(Q^{2}\right)$, and coefficient of determination $\left(R^{2}\right)$

\begin{tabular}{lllllllll}
\hline Paths & Beta & S.E & t-stat & p-value & Decision & $\mathbf{f}^{2}$ & $\mathbf{Q}^{2}$ & $\mathbf{R}^{2}$ \\
\hline BEm à BPO & 0.654 & 0.035 & 18.549 & 0.000 & Supported & 0.749 & 0.277 & 0.625 \\
BEm à EBU & 0.635 & 0.038 & 16.580 & 0.000 & Supported & 0.676 & & \\
BPO à EBE & 0.238 & 0.081 & 2.941 & 0.003 & Supported & 0.048 & \\
EBU à EBE & 0.582 & 0.078 & 7.426 & 0.000 & Supported & 0.287 & \\
\hline
\end{tabular}

Note. Relationship was measured in one-tail 


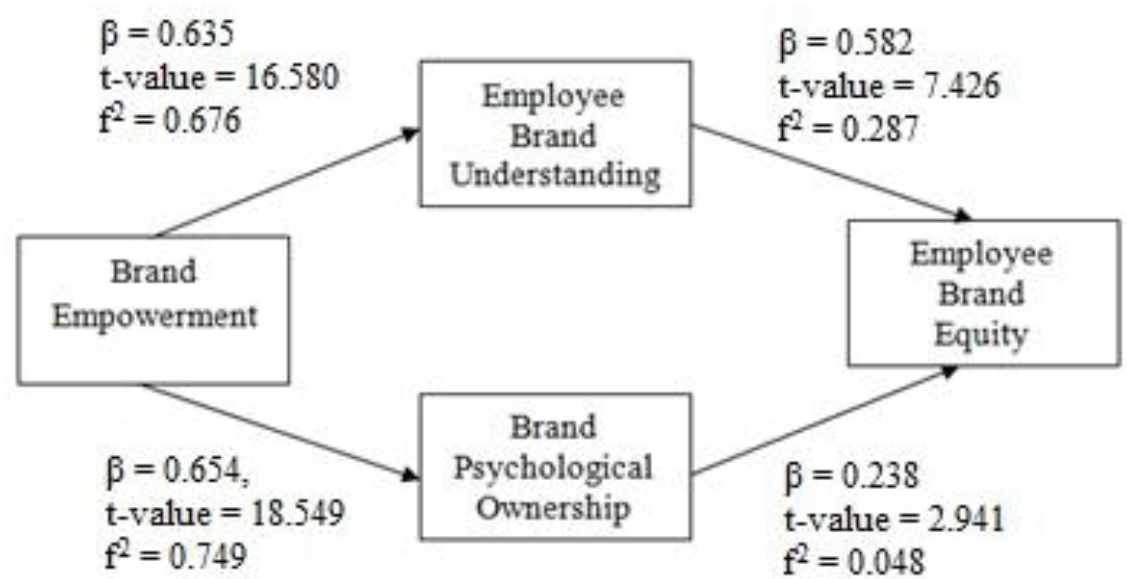

Figure 1. The Structural Model

Furthermore, employee brand understanding mediates the relationship between brand empowerment and employee brand equity $(\beta=0.496, \mathrm{t}$-value $=13.167, \mathrm{LLCI}=0.418$, $\mathrm{ULCI}=0.565)$. As the lower level of confidence interval and upper level of confidence interval do not exceed zero, the indirect path is significant, which means the relationship between brand empowerment and employee brand equity is successfully mediated by employee brand understanding. Similarly, the relationship between brand empowerment and employee brand equity is also mediated by brand psychological ownership $(\beta=0.496, \mathrm{t}$-value $=13.167, \mathrm{LLCI}=0.418, \mathrm{ULCI}$ $=0.565)$, as the LLCI and ULCI values also do not exceed zero. The direct relationship between brand empowerment and employee brand equity is nonsignificant, hence the indirect relationships are fully mediated by employee brand understanding and brand psychological ownership.

Table 6

\section{Indirect path Analysis}

\begin{tabular}{lcccccc}
\hline Paths & Beta & S.E & t-statistics & $\begin{array}{c}\text { LLCI } \\
\mathbf{( 5 \% )}\end{array}$ & $\begin{array}{l}\text { ULCI } \\
\mathbf{( 9 5 \% )}\end{array}$ & Decision \\
\hline BEm à EBE & 0.045 & 0.051 & 0.883 & -0.057 & 0.143 & No Mediation \\
BEm à EBU à EBE & 0.496 & 0.038 & 13.167 & 0.418 & 0.565 & Full Mediation \\
BEm à BPO à EBE & 0.470 & 0.041 & 11.542 & 0.403 & 0.560 & Full Mediation \\
\hline
\end{tabular}

Note. Relationship was measured in two-tail

\section{Conclusion and Discussion}

As mentioned, the objective of the research was to investigate the relationship between brand empowerment, brand psychological ownership, employee brand understanding, and employee brand equity, in addition to examining the mediating role of employee brand understanding and brand psychological ownership in the relationship between brand empowerment and employee brand equity.

The results of the study show that brand empowerment has a positive relationship with employee brand understanding and brand psychological ownership, while brand psychological ownership and employee brand 
understanding have a positive relationship with employee brand equity. Lastly, both employee brand understanding and brand psychological ownership have a mediating effect in the relationship between brand empowerment and employee brand equity.

Concerning brand empowerment, this has a positive relationship with brand psychological ownership and employee brand understanding (see Table 4). The F-square value for both relationships shows that brand empowerment has a substantial effect on brand psychological ownership and employee brand understanding. This confirmation of the relationship is in line with the job characteristics theory suggested by Hackman \& Oldham (1976) and Hackman \& Oldham (1975), where core job characteristics have a positive relationship with psychological states. As job characteristics theory suggests, the core job characteristic of brand empowerment had a strong relationship with the employee psychological states brand psychological ownership and employee brand understanding. Hence, the findings of this study are in line with the job characteristics theory suggested by Hackman \& Oldham (1976) and Hackman \& Oldham (1975).

Furthermore, brand psychological ownership and employee brand understanding also have a positive relationship with employee brand equity. The results of the study are also in line with past studies as well as with job characteristics theory. According to job characteristics theory, employee psychological states positively influence organizational and personal outcomes (Hackman \& Oldham, 1975). In this study, employee psychological states, namely brand psychological ownership and employee brand understanding, also have a positive relationship with personal outcome, i.e. employee brand equity. Past studies also supported this study's findings, where brand psychological ownership significantly influenced employee behavior that reflects brand values (Chang et al., 2012, 2015; Chiang, 2009; Chiang et al., 2013) and employee brand understanding positively influenced the personal outcome, i.e. employee brand equity (King \& So, 2015; Piehler et al., 2016b; Xiong et al., 2013). According to the results of the study, employee brand understanding has a substantial effect on employee brand equity, but the effect of brand psychological ownership is low since the effect size of employee brand understanding is higher than that of brand psychological ownership.

According to the results of the study, brand psychological ownership and employee brand understanding mediate the relationship of between brand empowerment and employee brand equity. The results are also in line with the job characteristics theory suggested by Hackman and Oldham (1976) and Hackman and Oldham (1975), where employee psychological states mediate the relationship between core job characteristics and personal outcomes. As shown in the study, brand psychological ownership and employee brand understanding are the psychological states of the employees that feature in the relationship between core job characteristics (brand empowerment) and employee personal outcome (employee brand equity).

\section{Managerial Implications}

This research was conducted among the employees of the banking sector of Pakistan, which includes public sector banks, private sector banks, Islamic banks, and foreign banks. In order to show employee brand equity in the banking sector, employee brand understanding is very much an important variable. By understanding brand values, these employees can better exhibit brand-related behaviors that represent brand values. Without any doubt, brand psychological ownership is an important variable, but employee brand understanding is an even more powerful tool to present the brand through employees' behavior, because it has a larger effect size. For this reason, the key to engendering employee brand equity is employee brand understanding. Therefore, empowering employees is the antecedent that creates employee brand confidence to exhibit behaviors related to the brand. 


\section{Limitation and Future Recommendation}

This study focused on employees in the Pakistani banking sector, which has four types of banks. A multi-group analysis of different types of banks is recommended for future studies. Similarly, a comparative study of different countries is suggested for future research. Moreover, there is a limited number of studies that focus on the antecedents of brand psychological ownership and employee brand understanding. Therefore, more research efforts are needed to explore new antecedents for both variables.

\section{References}

Aamir, I. (2016, march 4). Change is afoot in Pakistan's banking sector. World Finance. Retrieved from https://www.worldfinance.com/ banking/change-is-afoot-in-pakistans-bankingsector

Aazim, M. (2016). Banks eyeing business surge. Retrieved from https://www.dawn.com/ news/1233739, DAWN

Ahmad, A. (2010). A comparative study of Islamic banking in Pakistan: Proposing and testing a model (Doctoral dissertation), Islamabad, Pakistan: Foundation University.

Altaf, M., Mokhtar, S. S. M., \& Ghani, N. H. A. (2017). Employee critical psychological states as determinants of employee brand equity in banking: A multi-group analysis. Banks and Bank Systems, 12(3), 61-73.

Bateson, J. E. G. (1995). Managing services marketing: Text and readings. USA: Dryden Press.

Beyerlein, M. (2006). Viability of the job characteristics model in a team environment: Prediction ofjob satisfaction and potential moderators (Dissertação de mestrado). University of North Texas. Denton, TX, United States.
Boone, L. E., \& Kurtz, D. L. (2012). Contemporary Marketing, 2013 update edition. Eagan, MN : South-Western/Cengage Learning.

Bowen, D. E., \& Lawler III, E. E. (2006). The empowerment of service workers: What, why, how, and when. Managing innovation and change, 155-169.

Bravo, R., Montaner, T., \& Pina, J. M. (2010). Corporate brand image in retail banking: Development and validation of a scale. The Service Industries Journal, 30(8), 1199-1218.

Burmann, C., Jost-Benz, M., \& Riley, N. (2009). Towards an identity-based brand equity model. Journal of Business research, 62(3), 390-397.

Burmann, C., \& König, V. (2011). Does Internal brand management really drive brand commitment in shared-service call centers? Journal of brand management, 18(6), 374-393.

Burmann, C., \& Zeplin, S. (2005). Building brand commitment: A behavioural approach to internal brand management. The Journal of Brand Management, 12(4), 279-300.

Burmann, C., Zeplin, S., \& Riley, N. (2009). Key determinants of internal brand management success: An exploratory empirical analysis. Journal of brand management, 16(4), 264-284.

Chang, A., Chiang, H.-H., \& Han, T.-S. (2012). A multilevel investigation of relationships among brand-centered HRM, brand psychological ownership, brand citizenship behaviors, and customer satisfaction. European Journal of marketing, 46(5), 626-662.

Chang, A., Chiang, H.-H., \& Han, T.-S. (2015). Investigating the dual-route effects of corporate branding on brand equity. Asia Pacific Management Review, 20(3), 120-129.

Chelladurai, P. (2006). Human resource management in sport and recreation. Champaign, IL: Human Kinetics. 
Chiang, H. H. (2009). A study of the antecedent and concequence of brand psychological ownership: Scale development and multilevel approaches. (Doctoral thesis), Institute of Business Management, National Chengchi University.

Chiang, H.-H., Chang, A., Han, T.-S., \& McConville, D. (2013). Corporate branding, brand psychological ownership and brand citizenship behaviour: Multilevel analysis and managerial implications. Journal of General Management, 39(1), 55-80.

Conger, J. A., \& Kanungo, R. N. (1988). The empowerment process: Integrating theory and practice. Academy of management review, 13(3), 471-482.

DiJulius, J. R. (2011). What's the secret?: To providing a world-class customer experience. New Jersey: Wiley.

Drigă, I., \& Dura, C. (2014). The financial sector and the role of banks in economic development. Paper presented at the 6th International Multidisciplinary Symposium "Universitaria SIMPRO. Retrieved from https://www.upet. ro/simpro/2014/proceedings/09\%20-\%20 ECONOMICS\%20AND\%20PUBLIC\%20 ADMINISTRATION/9.2.pdf

Gara, A. (2016, may 25). The World's largest banks in 2016: China keeps top three spots but jpmorgan rises. Forbes. Retrieved from https://www.forbes. $\mathrm{com} /$ sites/antoinegara/2016/05/25/the-worldslargest-banks-in-2016-china-keeps-top-threespots-but-jpmorgan-rises/\#725f7c316417

Hackman, J. R., \& Oldham, G. R. (1975). Development of the job diagnostic survey. Journal of Applied Psychology, 60(2), 159.

Hackman, J. R., \& Oldham, G. R. (1976). Motivation through the design of work: Test of a theory. Organizational behavior and human performance, 16(2), 250-279.
Hair, J. F., Hult, G. T. M., Ringle, C., \& Sarstedt, M. (2016). A Primer on partial least squares structural equation modeling (PLS-SEM). Thousand Oaks: SAGE Publications.

Hankinson, G. (2012). The measurement of brand orientation, its performance impact, and the role of leadership in the context of destination branding: An exploratory study. Journal of Marketing Management, 28(7-8), 974-999.

Harman, D. (1967). A single factor test of common method variance. Journal of Psychology, 35, 359-378.

Hartline, M. D., \& Ferrell, O. C. (1996). The management of customer-contact service employees: An empirical investigation. The Journal of Marketing, 6O(4), 52-70.

Hennig-Thurau, T., \& Hansen, U. (2013). Relationship marketing: Gaining competitive advantage through customer satisfaction and customer retention. Berlim: Springer Science \& Business Media.

Hirvonen, S., Laukkanen, T., \& Reijonen, H. (2013). The brand orientation-performance relationship: An examination of moderation effects. Journal of brand management, 20(8), 623-641.

Houreld, K. (2015, april 20). China and Pakistan launch economic corridor plan worth $\$ 46$ billion. Reuters World News. Retrieved from https://www. reuters.com/article/us-pakistan-china/china-andpakistan-launch-economic-corridor-plan-worth46-billion-idUSKBNONA12T20150420

Husain, I. (2005). Banking sector reforms in Pakistan. Blue Chip-The Business People's Magazine, 5, 1-7.

Ind, N. (2007). Living the brand: How to transform every member of your organization into a brand champion. London; Philadelphia: Kogan Page Publishers. 
Kahn, R. L., Wolfe, D. M., Quinn, R., Snoek, J. D., \& Rosenthal, R. A. (1964). Organizational stress. New York: Wiley.

King, C., \& Grace, D. (2008). Internal branding: Exploring the employee's perspective. Journal of brand management, 15(5), 358-372.

King, C., \& Grace, D. (2009). Employee based brand equity: A third perspective. Services Marketing Quarterly, 30(2), 122-147.

King, C., \& Grace, D. (2010). Building and measuring employee-based brand equity. European Journal of Marketing, 44(7-8), 938-971.

King, C., Grace, D., \& Funk, D. C. (2012). Employee brand equity: Scale development and validation. Journal of brand management, 19(4), 268-288.

King, C., \& So, K. K. F. (2015). Enhancing hotel employees' brand understanding and brandbuilding behavior in China. Journal of Hospitality \& Tourism Research, 39(4), 492-516.

King, C., So, K. K. F., \& Grace, D. (2013). The influence of service brand orientation on hotel employees' attitude and behaviors in China. International Journal of Hospitality Management, 34, 172-180.

Krejcie, R. V., \& Morgan, D. W. (1970). Determining sample size for research activities. Educational and Psychological Measurement, 30(3), 607-610.

Lee, Y.-K., Nam, J.-H., Park, D.-H., \& Ah Lee, K. (2006). What factors influence customeroriented prosocial behavior of customer-contact employees? Journal of services marketing, 20(4), 251-264.

Lytle, R. S., Hom, P. W., \& Mokwa, M. P. (1998). SERV* OR: A managerial measure of organizational service-orientation. Journal of Retailing, 74(4), 455-489.
Menon, S. (2001). Employee empowerment: An integrative psychological approach. Applied Psychology, 50(1), 153-180.

Miles, S. J., \& Mangold, G. (2004). A conceptualization of the employee branding process. Journal of Relationship Marketing, 3(23), 65-87.

Mokhtar, S. S. M., Altaf, M., \& Ghani, N. H. A. (2018). Employee brand equity and brand empowerment in Islamic banking: Mediating role of brand psychological ownership. Academy of Accounting and Financial Studies Journal, 22, 1-5.

Morhart, F. M., Herzog, W., \& Tomczak, T. (2009). Brand-specific leadership: Turning employees into brand champions. Journal of Marketing, 73(5), 122-142.

Oldham, G. R., \& Hackman, J. R. (2010). Not what it was and not what it will be: The future of job design research. Journal of organizational behavior, 31(2-3), 463-479.

Parker, S. K., Wall, T. D., \& Jackson, P. R. (1997). "That's not my job": Developing flexible employee work orientations. Academy of Management journal, 40(4), 899-929.

Peccei, R., \& Rosenthal, P. (2001). Delivering customer-oriented behaviour through empowerment: An empirical test of HRM assumptions. Journal of Management Studies, 38(6), 831-857.

Peng, H., \& Pierce, J. (2015). Job-and organization-based psychological ownership: Relationship and outcomes. Journal of Managerial Psychology, 30(2), 151-168.

Piehler, R., King, C., Burmann, C., \& Xiong, L. (2016). The importance of employee brand understanding, brand identification, and brand commitment in realizing brand citizenship behaviour. European Journal of marketing, 50(9/10), 1575-1601. 
Pierce, J. L., Kostova, T., \& Dirks, K. T. (2001). Toward a theory of psychological ownership in organizations. Academy of management review, 26(2), 298-310.

Pierce, J. L., Kostova, T., \& Dirks, K. T. (2003). The state of psychological ownership: Integrating and extending a century of research. Review of general psychology, 7(1), 84.

Podsakoff, P. M., MacKenzie, S. B., Paine, J. B., \& Bachrach, D. G. (2000). Organizational citizenship behaviors: A critical review of the theoretical and empirical literature and suggestions for future research. Journal of Management, 26(3), 513-563.

Quinn, R. E., \& Spreitzer, G. M. (1997). The road to empowerment: Seven questions every leader should consider. Organizational Dynamics, 26(2), 37-49.

Rand Corporation (2001). A million random digits with 100,000 normal deviates. Santa Monica, CA: Autor.

Ringle, C. M., Wende, S., \& Becker, J.-M. (2015). SmartPLS 3: Boenningstedt: SmartPLS GmbH. Retrieved from http://www. smartpls. com

Rousseau, D. M. (1989). Psychological and implied contracts in organizations. Employee Responsibilities and Rights Journal, 2(2), 121-139.

Rousseau, D. M., \& Shperling, Z. (2003). Pieces of the action: Ownership and the changing employment relationship. Academy of management review, 28(4), 553-570.

State Bank of Pakistan. (2016). Statistics on scheduled banks in Pakistan. Pakistan: Autor.

Schmitt, B. (2012). The consumer psychology of brands. Journal of consumer Psychology, 22(1), 7-17.

Thomson, K., Chernatony, L., de, Arganbright, L., \& Khan, S. (1999). The buy-in benchmark: How staff understanding and commitment impact brand and business performance. Journal of Marketing Management, 15(8), 819-835.

Van Dyne, L., \& Pierce, J. L. (2004). Psychological ownership and feelings of possession: Three field studies predicting employee attitudes and organizational citizenship behavior. Journal of organizational behavior, 25(4), 439-459.

Waleed, A., Shah, M., \& Mughal, M. K. (2015). Comparison of Private and Public Banks Performance. IOSR Journal of Business and Management, 17(7), 32-38.

Welch, M. (2012). Appropriateness and acceptability: Employee perspectives of internal communication. Public Relations Review, 38(2), 246-254.

Xiong, L., King, C., \& Piehler, R. (2013). “That's not my job": Exploring the employee perspective in the development of brand ambassadors. International Journal of Hospitality Management, 35, 348-359. 


\section{Appendix A - Population and Sampling}

\begin{tabular}{lccccc}
\hline Public Sector Banks & $\begin{array}{c}\text { Number of Employees } \\
\text { as per Dec 2015 }\end{array}$ & $\begin{array}{c}\text { Total Number of } \\
\text { Branches 2015 }\end{array}$ & Percentage & $\begin{array}{c}\text { Selected } \\
\text { Branches }\end{array}$ & $\begin{array}{c}\text { Questionnaires } \\
\text { Distributed }\end{array}$ \\
\hline National Bank & 15548 & 1360 & 64.73 & 65 & 390 \\
First Women Bank & 564 & 43 & 2.05 & 2 & 12 \\
Sindh Bank & 1985 & 217 & 10.33 & 10 & 60 \\
Bank of Khyber & 2448 & 117 & 5.57 & 6 & 36 \\
The Bank of Punjab & 6739 & 364 & 17.33 & 17 & 102 \\
Total & 27248 & 2101 & $100 \%$ & 100 & 600 \\
\hline
\end{tabular}

\section{Appendix B - Instruments used in study}

Employee Brand Equity Scale

\begin{tabular}{|c|c|c|}
\hline Dimensions & Items & Source \\
\hline \multirow{4}{*}{$\begin{array}{l}\text { Brand } \\
\text { Endorsement }\end{array}$} & 1. I say positive things about the bank (brand) I work for to others & King et al. (2012) \\
\hline & $\begin{array}{l}\text { 2. I would recommend the bank (brand) I work for to someone } \\
\text { who seeks my advice }\end{array}$ & \\
\hline & 3. I enjoy talking about the bank (brand) I work for to others & \\
\hline & 4. I talk positively about the bank (brand) I work for to others & \\
\hline \multirow{4}{*}{$\begin{array}{l}\text { Brand } \\
\text { Allegiance }\end{array}$} & 5. I plan to be with the bank (brand) I work for, for a while & \\
\hline & 6. I plan to be with the bank (brand) I work for 5 years from now & \\
\hline & $\begin{array}{l}\text { 7. I would turn down an offer from another bank (brand) if it } \\
\text { came tomorrow }\end{array}$ & \\
\hline & 8. I plan to stay with the Bank (brand) I work for & \\
\hline \multirow{3}{*}{$\begin{array}{l}\text { Brand } \\
\text { Consistent } \\
\text { Behavior }\end{array}$} & $\begin{array}{l}\text { 9. I demonstrate behaviors that are consistent with the brand } \\
\text { promise of the bank I work for }\end{array}$ & \\
\hline & $\begin{array}{l}\text { 10. I consider the impact on my bank's brand before } \\
\text { communicating or taking action in any situation }\end{array}$ & \\
\hline & $\begin{array}{l}\text { 11. I am always interested to learn about my ank's brand and what } \\
\text { it means to me in my role }\end{array}$ & \\
\hline
\end{tabular}

CODING: Brand Endorsement (EBE_EN1 to EBE_EN4), Brand Allegiance (EBE_BA5 to EBE_BA8), Brand Consistent Behavior (EBE_BCB9 to EBE_BCB11) 


\begin{tabular}{|c|c|c|}
\hline Dimensions & Items & Source \\
\hline \multirow[t]{4}{*}{ Brand Confidence } & 1. I know how to live our brand in my daily work. & Piehler et al. (2016) \\
\hline & 2. I know how to act brand consistent in my daily work. & \\
\hline & 3. I know how to implement our brand in my daily work. & \\
\hline & 4. I know how to deliver our brand promise in my daily work. & \\
\hline \multirow[t]{3}{*}{ Brand Relevance } & 5. A strong brand is of great importance for our bank's success. & \\
\hline & 6. Our brand is an important asset of our bank. & \\
\hline & 7. Brand success is directly related to our bank's success. & \\
\hline \multirow[t]{3}{*}{ Behavioral Relevance } & 8. With my behavior I can affect customers' perceptions of our brand. & \\
\hline & $\begin{array}{l}\text { 9. By living our brand face to face with other employees I can strengthen our } \\
\text { brand in the bank. }\end{array}$ & \\
\hline & 10. With my behavior, I can affect brand success. & \\
\hline \multirow[t]{3}{*}{ Brand Knowledge } & 11. I know what our brand stands for. & \\
\hline & 12. I know our brand identity. & \\
\hline & 13. I know our brand promise. & \\
\hline
\end{tabular}

CODING: Brand Confidence (EBU_BC1 to EBU_BC4), Brand Relevance (EBU_BR5 to EBU_BR7), Brand Behavioral Relevance (EBU_BeR8 to EBU_BeR10), Brand Knowledge (EBU_BK11 to EBU_BR14)

Brand Empowerment Scale

\begin{tabular}{lll}
\hline \multicolumn{1}{c}{ Dimensions } & \multicolumn{1}{c}{ Items } & \multicolumn{1}{c}{ Source } \\
\hline Uni-Dimensional & 1. & $\begin{array}{l}\text { I feel like I can make a lot of inputs to deciding how to accomplish my role as a Morhart } e t \text { al. (2009) } \\
\text { brand representative. }\end{array}$ \\
2. & $\begin{array}{l}\text { I am free to express my ideas and opinions on how to live my role as a brand } \\
\text { representative. } \\
\text { 3. }\end{array}$ \\
& $\begin{array}{l}\text { There is not much opportunity for me to decide for myself how to live up to my } \\
\text { role as a brand representative. }\end{array}$ \\
4. & $\begin{array}{l}\text { Employees often make important customer decisions without seeking manage- } \\
\text { ment approval. }\end{array}$ \\
5. & $\begin{array}{l}\text { Employees have the freedom and authority to act independently in order to } \\
\text { provide excellent service. }\end{array}$
\end{tabular}

CODING: Brand Empowerment (BEm1 to BEm5) 
Brand Psychological Ownership Scale

\begin{tabular}{|c|c|c|}
\hline Dimensions & Items & Source \\
\hline \multirow{3}{*}{$\begin{array}{l}\text { Congruence between } \\
\text { Brand Image and } \\
\text { Individuals }\end{array}$} & $\begin{array}{l}\text { 1. I am willing to implement brand value because I feel my personal value is con- } \\
\text { sistent with the bank's brand value. }\end{array}$ & Chang et al. (2012) \\
\hline & $\begin{array}{l}\text { 2. I hope family and friends feel that my image is consistent with the bank's brand } \\
\text { image. }\end{array}$ & \\
\hline & $\begin{array}{l}\text { 3. I hope my customers' feel that my service is consistent with the bank's brand } \\
\text { image. }\end{array}$ & \\
\hline $\begin{array}{l}\text { Responsibility for } \\
\text { Maintaining Brand }\end{array}$ & 4. I feel I am praised when the bank's brand is praised. & \\
\hline Image & 5. I defend the bank's brand image when others criticize it. & \\
\hline & 6. When others criticize the bank's brand, I will improve defects. & \\
\hline \multirow{3}{*}{$\begin{array}{l}\text { Brand Value } \\
\text { Effectiveness }\end{array}$} & 7. I often transmit positive brand value to my friends and family. & \\
\hline & $\begin{array}{l}\text { 8. I can successfully transmit the bank's brand value in the process of interacting } \\
\text { with customers. }\end{array}$ & \\
\hline & 9. I pay attention to opinions of customers and even make friends with them. & \\
\hline
\end{tabular}

CODING: Congruence between Brand Image and Individuals (BPO_CON1 to BPO_CON3), Responsibility for Maintaining Brand Image (BPO_RES4 to BPO_RES6), Brand Value Effectiveness (BPO_EFF7 to BPO_EFF9)

\section{Supporting Agencies:}

NIL

\section{About the Authors:}

Mohsin Altaf, PhD in Marketing, Universiti Utara Malaysia, Sintok, Malaysia. E-mail: mohsin.iltaf@gmail.com ORCID

(iD) 0000-0002-7377-7801

Arfan Shahzad, PhD in Business Administration, Universiti Utara Malaysia, Sintok, Malaysia.

E-mail: arfan@uum.edu.my

ORCID

(iD) 0000-0002-2218-4619

\section{Contribution of each author}

\begin{tabular}{lcc}
\hline Contribution & Mohsin Altaf & Arfan Shahzad \\
\hline 1. Definition of research problem & $\sqrt{ }$ \\
2. Development of hypotheses or research questions (empirical studies) & $\sqrt{ }$ \\
3. Development of theoretical propositions (theoretical work ) & $\sqrt{ }$ \\
4. Theoretical foundation/ Literature review & $\sqrt{ }$ \\
5. Definition of methodological procedures & $\sqrt{ }$ \\
6. Data collection & $\sqrt{ }$ \\
7. Statistical analysis & $\sqrt{ }$ \\
8. Analysis and interpretation of data & $\sqrt{ }$ \\
9. Critical revision of the manuscript & $\sqrt{ }$ \\
10. Manuscript writing & $\sqrt{ }$ & $\sqrt{ }$ \\
\end{tabular}

